O eixo e a roda, Belo Horizonte, v.25, n.2, p. 297-318, 2016

\title{
Paradoxo e animismo: Osman Lins, um selvagem civilizado*
}

\section{Paradox and animism: Osman Lins as a civilized savage}

João Guilherme Dayrell

Universidade Federal de Minas Gerais, Belo Horizonte / Brasil joaogdms@gmail.com

Resumo: Em uma famosa objeção à comparação de sua literatura com aquela engendrada pelos nouveaux romanciers franceses, Osman Lins afirmava ser tal corrente literária extremamente civilizada enquanto, ao contrário, via-se (a si mesmo e a sua prosa) como "um tanto civilizado, mas [...] mais ou menos primitivo, um selvagem civilizado". Considerando que o primitivismo osmaniano é colocado pelo autor como algo da ordem dos "instintos" e do "incompreensível", pretendemos com este artigo demonstrar como este aspecto foi identificado de maneira precisa pelo crítico franco-lusitano Álvaro Manuel Machado, sobretudo quando este autor propõe o "paradoxo" e o "animismo" como chaves de leitura de Nove, novena e Avalovara. Em seguida, aclararemos o interesse de Lins pela coincidentia oppositorum e pelo "olhar" dos animais propostos por Mircea Eliade, além de abordar o protagonismo dos viventes não humanos e da natureza em geral em suas duas obras supracitadas. Finalmente, exporemos como Lins, em sua literatura, elabora uma veemente crítica à pretensão à racionalidade pura.

Palavras-chave: Osman Lins; animismo; paradoxo; primitivismo.

Abstract: In a notorious objection to the comparison of his writings with those of the French Nouveau Roman, Osman Lins claimed the latter to be a highly civilized literary current, whereas he and his own prose works were "civilized but $[\ldots]$ more or less primitive, a civilized savage". Lins

\footnotetext{
* Este trabalho contou com o apoio da FAPEMIG.
} 
postulated his primitivism as something along the lines of "instincts" and of the "incomprehensible". This paper aims at demonstrating how this issue has been pointed out by the Franco-Lusitanian critic Alvaro Manuel Machado, especially when this author proposes "paradox" and "animism" as keys to reading Nove, novena and Avalovara. Henceforth it will show Lins's interest in the coincidentia oppositorum and in the "gaze" of animals proposed by Mircea Eliade, besides discussing the role of non-humans and nature in general in Lins's works mentioned above. Finally, it will expose how Lins elaborates in his works a sharp criticism of the claim to pure rationality.

Keywords: Osman Lins; animism; paradox; primitivism.

Recebido em 17 de dezembro de 2015. Aprovado em 26 de abril de 2016.

\author{
"A luz, o sol, o ar livre \\ envolvem o sonho do engenheiro. \\ O engenheiro sonha coisas claras: \\ superfícies, tênis, um copo de água. \\ O lápis, o esquadro, o papel; \\ o desenho, o projeto, o número: \\ o engenheiro pensa o mundo justo, \\ mundo que nenhum véu encobre." \\ (João Cabral de Melo Neto. O engenheiro).
}

"Manipula a romancista um universo instrumental
fechado, havendo-se apenas com o que Claude
Lévi-Strauss chama de meios-limites, 'um
conjunto, continuamente restrito, de utensílios e
de materiais'. Mas temos de admitir que exerce
o bricolage com grande paciência e senso de
ordenação." (Osman Lins. A rainha dos cárceres da Grécia).

"Para fugir de ser peixe, sobre os deltas vamos construindo, de cimento, de aço, de madeira, um sistema de pontes [...]."

(Osman Lins. Nove, novena). 
Em uma entrevista concedida a Esdras do Nascimento e publicada no jornal O Estado de S. Paulo em 1974, Osman Lins, com o objetivo de rejeitar uma possível filiação aos nouveaux romanciers franceses, evocava uma boutade - que hoje é bastante conhecida de sua crítica -, na qual classificava o Nouveau Roman como uma corrente literária "intelectualizada e civilizada", ao que completava: "eu tenho algo de intelectual mas sou primitivo. No sentido de que os instintos, as coisas elementares, o incompreensível contam em mim" (LINS, 1979, p. 179). ${ }^{1}$ Uma variação da sentença poderia ser encontrada em outra entrevista, na qual o pernambucano, contrapondo-se à literatura "extremamente civilizada" dos franceses, postulava-se como "um tanto civilizado, mas [...] mais ou menos primitivo, um selvagem civilizado" (LINS, c1981). Neste sentido, ainda, o escritor marcava uma diferença incontornável entre os autores latino-americanos e os europeus de uma maneira geral, pois, enquanto para estes os mitos arcaicos - provavelmente se referindo ao conjunto de mitologias oriundo das comunidades ditas tradicionais, as indígenas - eram objeto de estudo, para aqueles as mitologias eram parte integrante das obras (LINS, 1979, p. 172).

O vínculo entre o primitivismo e sua obra literária, especialmente aquela engendrada de Nove, novena, de 1966, em diante, é postulado pelo pernambucano recorrentemente, embora sua abordagem sobre este tema seja, em muitos momentos, conflituosa. Em 1969, por exemplo, Lins declarava ser "o real uma escuridão cegante", fato este que impelia seu texto à racionalidade, pois, como alertava, "o irracionalismo tem muitas armadilhas" (LINS, 1979, p. 147). Neste mesmo ensejo, porém, o escritor estabelecia uma correlação entre a criação de uma obra literária e o ato de fazer "um bicho com as mãos, pêlo por pêlo" (LINS, 1979, p. 147). Ao discorrer sobre a estrutura de Avalovara (1973), sua obra mais emblemática (o termo "estrutura" é usado pelo escritor para se diferenciar de Guimarães Rosa e James Joyce), Lins indicava que ela funcionava como "uma jaula dentro da qual se movem animais selvagens. Inquietude, angústia, desespero, tudo o que faz parte da nossa condição" (LINS, c1981). Além disso, para o autor, este livro

\footnotetext{
${ }^{1}$ A entrevista chega a nós pelo livro póstumo organizado por Julieta de Godoy Ladeira, intitulado $O$ evangelho na taba, assim como as outras confissões do autor, embora algumas sejam concedidas em momentos diferentes, o que ficará registrado ao longo deste texto.
} 
não apresentaria qualquer obscuridade, uma vez que nele era como "se eu tentasse transmitir", explica, "com a maior exatidão possível um sonho, ou vários sonhos" (LINS, c1981), o que se dava, igualmente, em Nove, novena, como comprova a menção da personagem da narrativa "Um ponto no círculo" ao hieróglifo: tal forma gráfica possuía o poder de mentar a intelectualidade e a natureza, a construção do intelecto e a evocação mágica. "Isto não para obedecer teoria ou programa", dizia Lins a Esdras do Nascimento, "mas porque tenho esta contradição: a de debater-me entre a ânsia de compreender e a certeza de que tudo é mistério" (LINS, 1979, p. 181), finalizava.

Esta posição ambígua de Lins e, sobretudo, o modo como ela se manifestava em sua literatura teve, justamente na França, um interessante diagnóstico. Trata-se de uma pequena resenha publicada em 1971 no Magazine Littéraire por Álvaro Manuel Machado, crítico literário português radicado em Paris e responsável pela indicação de Nove, novena a Maurice Nadeau, então diretor da Denöel/Lettres - como mostrou Gaby Friess Kirsch (1998). Machado, em seu comentário a Nove, novena, obra que, em Paris, recebeu o título de Retable de Sainte Joana Carolina (1971), conforme a tradução de Maryvonne Lapouge, sublinha que Lins era um escritor "essencialmente paradoxal", uma vez que se apresentava "geométrico nas técnicas narrativas e barroco no espírito que comanda[va] estas técnicas” (MACHADO, 1971, p. 37, tradução nossa), espírito este marcado pelo horror ao vazio característico dos artistas barrocos - portanto, excessivo, pletórico, superabundante. $\mathrm{O}$ ímpeto de ordenação permitiria ao escritor buscar uma síntese, sorte de essência invariável no interior do texto, o que se coadunaria, por sua vez, à sua procura por uma "verdade mítica", "uma unidade religiosa" que se manifestava nos enredos, finalmente, através da "comunhão dos homens entre si e dos homens com a natureza" (MACHADO, 1971, p. 37-38). Esta invariante, diz Machado (1971), era transferida, em Nove, novena, aos animais, como a elefanta Hahn, os insetos do conto "Noivado", os escorpiões do "Retábulo de Santa Joana Carolina", os cavalos de "Pastoral", que tomavam formas diversas e se integravam à alma humana. Neste sentido, o crítico franco-lusitano arremata que o "animismo" seria uma das marcas fundamentais desta obra. Porém, tal essência no interior dos bichos, das coisas, assim como a identidade das personagens, encontrar-se-iam constantemente ameaçadas pela erosão provocada pelo tempo, o que é justamente o que acaba se passando na 
obra de Lins, segundo o crítico. "Tudo se reduz, finalmente, ao acaso e ao caos e o homem se torna, eternamente, autor de si mesmo", finaliza Machado (1971, p. 38) em sua avaliação de Nove, novena.

É certo que o texto de Machado foi influenciado pelo prefácio à edição francesa de Nove, novena, escrito por Leyla Perrone-Moisés, embora o crítico português não faça qualquer referência aos "Novos romancistas", mencionados no texto da brasileira. A ideia da presença de uma "erosão" na literatura de Lins é proposta por Perrone-Moisés ao destacar o protagonismo, em Nove, novena, das "camadas geológicas", do "trabalho corrosivo dos insetos", da "força selvagem do animal indomado", o que levaria o pernambucano a ser "dominado pelo tema da perda, da destruição e da dispersão sob todos os seus aspectos: perda do momento presente, dos seres, das coisas; erosão, enterro, transformação, apagamento" (PERRONE-MOISÉS, [s.d.]). A natureza, portanto, desempenha, segundo esta crítica, um papel negativo na obra osmaniana, em oposição, por sua vez, ao mito e à geometria, já que aquela marca uma ausência de ruptura entre "universo escrito e universo significado" (estando este em transformação), e esta a necessidade de ordenar o caos, a destruição: ambos, em conjunto, dariam lugar a uma "geometria de fundo cosmogônico", diz Perrone-Moisés ([s.d.]). Destarte, para esta autora, a aspiração mítica (positiva) osmaniana em Nove, novena invoca dimensões arquetípicas que "ultrapassam a região" e "se liberam ao mesmo tempo de qualquer referência temporal" (PERRONE-MOISÉS, [s.d.]), ou seja, logra amplitudes a-históricas que convivem com a realidade em transformação - assim como, no Brasil, a tradição agrária, patriarcal e mística do nordeste coexiste com a industrialização do sul.

$\mathrm{O}$ aspecto substancial das mitologias arcaicas, sublinhamos, coloca ambos os críticos em acordo. No entanto, se para PerroneMoisés ([s.d.]) o mito figura uma oposição aos animais que, por sua vez, encenam a despesa, a transformação e a corrosão, para Machado (1971) o mito compartilha sua substância com os bichos, concedendo-lhes alma humana. De modo que, em Nove, novena, segundo este crítico, a essência se torna comum aos seres viventes (humanos e não humanos) e à natureza de maneira geral, o que, por outro lado, não os retira completamente da condição espaço-temporal, uma vez que tudo finda, em acordo com a conclusão de Machado (1971), no acaso e no caos. Assim, depreendemos que, segundo este crítico, Nove, novena porta em seu eixo basilar um processo de mão dupla, paradoxal e simultâneo, por 
meio do qual o metafísico (o mito, a essência) se torna físico (espaçotemporal, suscetivel à mudança, à transformação) e o fisico (a natureza e os bichos) se torna metafísico (ganham espírito, alma, o que só homens teriam), de onde o animismo osmaniano.

A suposta presença de uma a-historicidade no texto de Lins, salientada por Perrone-Moisés ([s.d.]), adquire contornos mais definidos quatro anos depois, quando o crítico, poeta, tradutor e amigo do escritor pernambucano, José Paulo Paes, publica o pequeno estudo "A palavra feita vida", que também passa a figurar como prefácio às posteriores edições brasileiras de Nove, novena. O ponto de Paes (2004, p. 209) é que Lins, da citada obra em diante, transgride "a linha de demarcação naturalista, realista ou verista entre o ficcional e o real", para recuperar, por meio de arquétipos como, por exemplo, a astrologia, a alquimia e a quiromancia, uma representação literária do "vislumbre de que o homem não é um joguete cujo destino seja regido pelas leis do acaso, mas um microcosmo sob o império da mesma simetria e número que regem o Universo todo". Segundo Paes, mediante estes arquétipos (a astrologia, a alquimia etc.), seria possível voltar às épocas primevas, "quando o homem não se sentia isolado do cosmos", diz o escritor paulista citando Carl Jung, porque, envolvido pela natureza, não havia perdido sua identidade "inconsciente com os fenômenos naturais" (JUNG, c1964, p. 85 apud PAES, 2004, p. 210, tradução do autor). ${ }^{2}$

Esta leitura de Paes não é fortuita: um olhar detido sobre os estudos de preferência de Lins, como os de Mircea Eliade (2011) sobre as religiões, os de Matila Ghyka (1952; 1953) sobre os números, ou o de Jacob van Lennep (1966) sobre a alquimia - obras que constavam em sua biblioteca,$-{ }^{3}$ revela que eles se reúnem em torno de uma mesma noção, qual seja, o supracitado conceito de arquétipo proposto e desenvolvido por Jung, sobre o qual gostaríamos de fazer uma breve observação. Para o psicólogo os arquétipos são imagens, formas primordiais, universais e a-históricas que asseguram os ciclos de conversões entre natureza e cultura, termos que aqui correspondem, respectivamente e como quer a tradição ocidental em sua soma de legado grego e cristianismo, a caos e

\footnotetext{
${ }^{2}$ JUNG, C. G. et al. Man and his symbols. New York: Dell, c1964.

${ }^{3}$ A biblioteca de Lins foi doada ao IEB - Instituto de Estudos Brasileiros - da USP. Para consulta de alguns destes dados pela internet, cf. a sistematização realizada em PEREIRA, 2012.
} 
ordem, sensível e inteligível, instinto e razão, transitório e permanente, múltiplo e uno, corpo e espírito, negativo e positivo etc. Neste sentido seguem as tertúlias selvagens para Jung: infantis, uma vez que estariam próximos à origem inconsciente e a-histórica, na qual há grande recorrência dos arquétipos, os indígenas realizariam inúmeros ritos justamente para trazer as imagens arquetípicas à leitura, impedindo, assim, o advento da sombra na imagem, do caos pré-consciente, responsável pela instauração de um estado no qual não há discernimento entre sujeito e objeto (JUNG, 2006, p. 32). Por isso tantos os indígenas como os civilizados teriam uma tendência a tentar sempre "banir o fantasma do inexplicável" (JUNG, 2006, p. 158), tarefa que na civilização é empreendida pelo "intelecto científico", que, por isso, finalmente, sempre "sucumbe de novo a tendências iluministas" (JUNG, 2006, p. 158). Neste sentido, Jung (2006, p. 183) recomenda estudarmos o arquétipo por uma ótica puramente fenomenológica, mantendo a imagem concreta, nítida e livre de ambiguidades, jamais a analisando segundo a arqueologia de suas ruínas, o seu contexto não original ou em sua essência.

Não há qualquer registro de menção a Jung feita por Lins, mas o pernambucano opta por colocar como epígrafe de Avalovara uma citação de Eliade, teórico que, apesar de dar prosseguimento à ideia de a-historicidade arquetípica junguiana, realiza uma sensível mudança com relação às concepções do psicólogo, a saber: para Eliade (2011, p. 95), ao contrário de procurar utilizar as tertúlias como amparo ao advento da sombra, os selvagens ou homens religiosos reatualizariam as mitologias através dos rituais para promover, intencionalmente, a "destruição e recriação periódicas" do mundo inteiro, ou do modo como este é concebido. Ou seja, haveria uma proposital imersão na sombra a fim de repetir gestos exemplares dos heróis mitológicos, tornando possível a toda a comunidade abrir e ressignificar o mundo pela reencenação da passagem do caos ao cosmos. Neste sentido Eliade (2011) postula a coincidentia oppositorum como conceito fundamental: vida e morte, positivo e negativo, bem e mal se confundem paradoxalmente nos rituais, pois para criar novamente o mundo é preciso destruí-lo, ao passo que a destruição evoca uma nova criação. Assim, o estado de cultura e as proibições que o asseguram (as leis) são transgredidas, como acontece nas orgias e no canibalismo cultural, por exemplo, possibilitando a profanação do sagrado e, logo, a sacralização do profano, tornando indiscerníveis criador e criatura, natureza e divindade, sujeito e objeto. Neste sentido 
Eliade (2011) nota que, para o indígena, o homem vê o mundo, é capaz de conhecê-lo, mas também é visto por ele, pois o animal, a árvore ou o rochedo podem ter um conselho para lhe dar. Daí o canibalismo, pois comer um tubérculo ou um porco equivale a comer um homem e viceversa, uma vez que os animais têm humanidade, capacidade de sabedoria, pois um dia foram humanos e, no ritual, este estado pré-cósmico, de continuidade do homem em relação ao meio circundante, é retomado.

É preciso levar em conta que Osman Lins declarou que seu pendor ao mito de maneira alguma o equiparava a Jorge Luis Borges, i.e., alguém que "recusava a história" (LINS, 1979, p. 219), ${ }^{4}$ o que nos chama atenção para o papel desta em sua literatura, que se queria, portanto, irredutível à busca pela a-historicidade. De modo que devemos nos indagar qual seria o papel da sombra, do incompreensível, do excesso na obra de Osman Lins e em meio a quais problemas estaria o ímpeto de ordenação. Na narrativa "Um ponto no círculo", presente em Nove, novena, uma boa imagem deste processo é traçada: uma anônima mulher, designada pela figura de um triângulo, estabelecia uma íntima afinidade entre si e os animais que há cinco mil anos habitavam a beira do rio Nilo, uma vez que estes possuíam índole mutável similar, por sua vez, ao caráter "múltiplo, vário e excessivo" da protagonista (LINS, 2004, p. 25). No caso dos animais, a escrita foi responsável por transmudá-los e prendêlos em "luminosas sínteses" (LINS, 2004, p. 25), impedindo-os de voar, nadar e cantar; já a mulher percebe, em um homem desconhecido, um olho de vidro capaz de conceder a ela perfis exatos e geométricos, tendo em vista que tais peças não veem o "transitório das coisas", não são "videntes e corruptíveis", explica a personagem; no entanto, são apenas, como conclui, "contempladores abstratos do eterno" (LINS, 2004, p. 23). Ao fim da narrativa, a mulher e o homem estabelecem entre si uma relação sexual e uma dança semelhante a um culto dionisíaco que da seguinte maneira é retratada: "somos dois corpos, somos um corpo" (LINS, 2004, p. 27), ${ }^{5}$ ou seja, não há somente uma união entre os dois

\footnotetext{
${ }^{4}$ Esta declaração de Osman Lins foi dada na entrevista "O desafio de Osman Lins", originalmente publicada na revista Escrita, ano II, n. 13, em 1976. Como mostraremos, tal crítica não livra o autor de usar, em sua literatura, procedimentos borgeanos, por assim dizer.

${ }^{5}$ Interessante notar como este conto se inicia descrevendo a personagem contemplando uma obra de arte, qual seja, um quadro com a imagem de Ana de Áustria. Ao fim, junto
} 
formando um, mas um enlace intermitente de distanciamento e contato, unidade e multiplicidade concomitantes. O homem, por sua vez, descreve, neste momento, uma explosão sensorial na qual a visão não ocupa o papel principal: "o pêlo de suas axilas, fulvos, úmidos [...] exalavam um cheiro resinoso [...]", a "resistência da pele, sua temperatura, o vibrar dos músculos e a descorada penugem, a meia altura das coxas, atenuavam a dureza que me desapontava no desenho das pernas, nos joelhos ósseos, não muito claros, e nos pés de veias salientes" (LINS, 2004, p. 27). Doravante a mulher declara sua decidida recusa em viver somente em seu rigor (positividade) ou em sua desordem (negatividade animal), optando por seguir entre "os ângulos dos geômetras e os bichos do furacão" (LINS, 2004, p. 29).

No conto "Perdidos e achados", uma personagem feminina igualmente indicada por um triângulo, ao presenciar o sumiço de uma criança numa praia de Recife, revela que "enquanto o outro falava, pedindo informações sobre a criança, um dispositivo qualquer foi posto a trabalhar nos seus olhos, transformados em súbitos órgãos penetrantes, sem piedade alguma [...]" (LINS, 2004, p. 171). A passagem parece reforçar a ideia do olho de vidro como dispositivo tecnológico que era, por sua vez, bastante comum no início do século XX, seja em Dziga Vertov, com sua câmera-olho (Cf. VERTOV, 1983), ou entre os "Novos romancistas" franceses, como exemplificam obras como Portrait d'un inconnu (1956), de Nathalie Sarraute, Le vent (1957), de Claude Simon e, principalmente, Le voyeur (1955), de Alain Robbe-Grilllet, nas quais diversas personagens portam, em seus corpos, olhos mecânicos que se

ao homem e formando com ele um casal em plena relação sexual, ambos engendram uma dança, que caracterizamos como dionisíaca. Em seu clássico sobre o tema, Friedrich Nietzsche (2004, p. 23) explicava que durante o estado do dionisíaco, análogo à embriaguez pois em ambos o indivíduo se abandona no "total esquecimento de si mesmo", "a natureza, alienada, inimiga ou subjugada, celebra sua reconciliação com o filho pródigo, o homem". Deste modo, "os animais falam, já a terra produz leite e mel, porque a voz do homem adquiriu uma ressonância de ordem sobrenatural. O homem [...] sente-se Deus [...], deixa de ser artista para se tornar obra de arte." (NIETZSCHE, 2004, p. 37). No conto de Osman Lins poderíamos dizer que as personagens deixam de ser contempladoras desinteressadas de uma obra de arte e se tornam elas mesmas uma obra de arte com sua dança. Agradeço aos alunos da disciplina "A literatura e a vida nua", que ministrei no primeiro semestre de 2016 na Faculdade de Letras da UFMG. Nossos diálogos sobre este conto de Lins resultaram nesta observação em rodapé. 
comportam como máquinas fotográficas ou filmadoras, permitindo a tais personagens, finalmente, descrever o mundo de forma impassível, exata, quando não geométrica.

Desta sorte temos em "Um ponto no círculo" a escrita e o olho de vidro cinemático como manifestações inscritas ao longo do transcurso da história - separadas, aliás, por cinco mil anos - como técnicas que parecem tentar controlar, administrar ou reduzir à síntese unitária aquilo que é múltiplo. Tal tarefa, lembramos rapidamente, também era comum à alquimia, como mostrou Jacob van Lennep (1966), cujo ímpeto era correlacionar a retirada do ouro (material puro e eterno) da matéria informe ao ato de angariar a ideia pura, a verdade, do mundo sensível. Este era figurado pelos elementos passivos e femininos, que deveriam ser submetidos à substância ativa, masculina, para se alcançar o solar "Uno-o-Todo", simbolizado, como infere Van Lennep (1966, p. 21), pela imagem de um "ponto circundado por um círculo". Aliás, lembramos que Platão, em seu Banquete, designava o andrógino como ser esférico e junção do feminino, originário da terra, com o masculino, filho do sol (cf. o texto da antiguidade na edição PLATÃO, 2012). No caso da narrativa osmaniana, como dito, a mulher rejeita a exclusiva negatividade ou positividade com o seu encontro regido pelo paradoxo "somos dois, somos um", ao passo que avulta a forma hieroglífica, na qual o aspecto sintético da escrita está conjugado com a imagem sensível e aberta. A legibilidade e o conhecimento se fazem presentes sem, no entanto, subsumir, por meio das sínteses luminosas, a multiplicidade não totalizável da vida biológica, na qual se incluem o aspecto corporal da própria personagem e os animais do Nilo. Assim, não há uma passagem pura da natureza à cultura que seria realizada, finalmente, pelo olho de vidro, pela escrita ou pela alquimia.

O tópico da escrita retorna em Nove, novena no conto " $O$ pentágono de Hahn" quando um escritor, enfrentando a esterilidade de sua vida e de sua criatividade, elogia a domesticação da elefanta Hahn ao comparar a submissão do animal com a necessidade de dominar ou extirpar palavras em estado selvagem para que, assim, possa-se engendrar o texto literário. No segundo quadro da narrativa deste homem, ele aparenta ser acometido por um arrebatamento no qual seu "eu" se arrefece; no terceiro, ele volta à resignação e ao tédio original. No último, ao ver Hahn se despedindo, um transe é novamente iniciado com o advento de uma música, tomando conta de todos que acompanham a elefanta, e ele presencia o homem do 
olifante que lhe diz: "escreva, não importa como nem o quê [...]” (LINS, 2004, p. 62). Um processo similar se dá com a garota indicada por uma flecha, que confessa ser a chegada de Hahn o início "de acontecimentos graves" em sua "vida apagada" (LINS, 2004, p. 32). Ela inicia um relacionamento amoroso/sexual com Bartolomeu, garoto que acompanha Hahn no circo, embora tal relação seja reprovada pela sociedade. Assim como o escritor, ela, em determinada passagem, dá a ver uma espécie de perturbação: "movendo-me, senti o volume das minhas ancas e tive a consciência de que no meu andar pesado, em meus quadris ondulosos, no tronco sem cintura, é possível descobrir, bastando para isso um pouco de maldade, semelhanças com Hahn" (LINS, 2004, p. 41). Ao final de sua empreitada ela escreve uma carta ao seu amante Bartolomeu, que da seguinte maneira se encerra: "despeço-me também de nosso amor incompreendido, que tão pouco viveu e tão feliz me tornou. Foi, apesar de tudo, o que de mais belo conheci na vida. Amar-te-ei sempre. Tua... Hahn" (LINS, 2004, p. 61).

Quem assina esta carta? É impossível dizer, mas aqui fica patente a relação do paradoxo com o animismo (lembrando que, de acordo com Platão e Aristóteles, para que algo possa ser um objeto de conhecimento ele não pode ser e não ser - o famoso princípio da não contradição) e como um evoca o outro: pois, se não é possível delimitar se é um humano ou um bicho que assina a carta, instaura-se a possibilidade de, por um lado, uma menina ter se transformado em animal, como ela já dava indícios, e, de outro, de a elefanta Hahn ter ascendido à linguagem humana e à escrita. Hahn e a menina são um corpo, são dois corpos; elas são e não são, e, justamente por isso, elas podem ser. Assim, não se instaura uma negatividade impermista, a exclusiva animalidade e ausência de comunicação, a pura diferença, variação ou violência, e nem há, em Osman Lins, a nosso ver, a positividade pura, a comunicação plena, a essência, a unidade, o amor pelo rigor da geometria. Esse fato encontra seu correspondente na própria escrita osmaniana, uma vez que ela nos comunica estórias que, no entanto, são atravessadas por lacunas de saber, pelo inexplicável, processo este que convida o leitor à participação - afinal, cabe àquele que lê responder quem assina a carta: Hahn, a menina, Osman Lins? Esta conjugação entre saber e não saber, luz e sombra, ângulos dos geômetras e bichos do furacão, a partir da qual é possível vislumbrar a natureza na cultura (o instinto, as coisas elementares, o incompreensível) e, também, a cultura na natureza (o 
animismo inscrito na ascensão de um elefante à escrita), cristalizados, por exemplo, na figura do hieróglifo ou na assinatura da carta da personagem de "O pentágono de Hahn", serve para, posteriormente, em Avalovara, Abel, escritor protagonista desta obra, elaborar, depois de muita reflexão, uma ideia de escrita literária possível. Antes, sublinhamos que junto a sua amante, personagem designada por um ponto no círculo seguido de duas antenas que os abrem ao infinito - $\odot-$-, Abel se debatia sobre o "cais em T" da cidade de Ubatuba, espécie de espaço das formas puras, geométricas, fenomenológicas e impassíveis, argumentando que aquele equilíbrio e aquela simetria perfeita ali presentes não se sustentavam. Assim, ele chega a uma conclusão sobre a ideia de ordem e, com isto, formula a tarefa de sua escrita:

- Empenho-me na conquista de uma afinação poética e legível entre a expressão e faces do real que permanecem como que selvagens, abrigadas - pela sua índole secreta - da linguagem e assim do conhecimento. Existem, mas veladas, à espera da nomeação, este segundo nascimento, revelador e definitivo. Consigo, por vezes, rápidas passagens -, alcançar o cerne do sensível. O combate quase corporal que sustento com a palavra liga-se a essas perfurações. Um esforço no qual venho amestrando aptidões mais ou menos embotadas; e para o qual, inclusive, convergem as pausas de sombra, os intervalos em que - sem realmente ver e sim apenas revendo - caço o oculto. O claro e evidente deixa-me frio (LINS, 1973, p. 223).

O que está atrás da linguagem, do conhecimento, é designado como selvagem, assim como fazia o escritor de "O pentágono de Hahn”. Com a nomeação - aí vemos um problema blanchotiano - ${ }^{6}$ o que está atrás da linguagem nasce pela segunda vez de maneira definitiva. De modo que o escritor, assumindo que o claro e evidente o deixa frio, busca alcançar o cerne do sensível através de um combate corporal com as palavras, no qual elas, ao invés de simplesmente proverem uma luminosa síntese da vida material, buscam o oculto, mantêm as sombras, perfurações,

\footnotetext{
${ }^{6}$ Osman Lins era um leitor de Maurice Blanchot, autor pelo qual mantinha grande apreço. Para o caso especificado, Cf. BLANCHOT, 2011, especialmente o texto "A literatura e o direito à morte".
} 
intervalos e aspectos insondáveis do real, que garantem, por sua vez, sua compleição primitiva. Abel sabia que não estava sozinho neste tipo de empreitada ao confessar que havia outros "textos com preocupações idênticas" às dele, "voltados para a decifração e mesmo para a invenção de enigmas (o que também é um modo de configurar o indizível)", o que quer dizer, segundo o protagonista, "textos não contaminados pela opressão" (LINS, 1973, p. 330). Com isto, fica patente que a escrita deve não apenas contatar as faces selvagens do real, mas, outrossim, produzi-las, configurando o indizível. "Escreva, não importa como nem o quê" - desta maneira, a escrita, em Lins ou em Abel (ambos, aliás, eram pernambucanos que haviam se instalado em São Paulo após uma estadia em Paris, além de serem igualmente escritores e ex-funcionários de banco), parece se vincular mais à despesa que à economia, ou seja, não nos parece se prestar unicamente a engendrar luminosas sínteses, mas se situar, como um hieróglifo, entre a intelectualidade e a natureza, a razão e a evocação mágica, os ângulos dos geômetras e os bichos do furacão.

A figura da opressão, da qual Abel livra sua escrita ao nela inserir a configuração do indizível, parece ter, em Avalovara, diversos matizes importantes, entre os quais listamos a título de exemplificação: a personagem Olavo Hayano e o Iólipo, a mais emblemática e explícita delas; a luta do escravo Loreius pela liberdade; a máquina do mundo sobre o corpo de $\odot$ e a ascensão do nazismo na Alemanha. Peguemos a primeira citada. Em um dos primeiros encontros de Abel com a amada, ele vindo do Nordeste e ela do Centro-Oeste do país para assistir a um eclipse, o escritor associa o rosto da parceira ao caráter duplo e multiplicador do dito evento astronômico e infere que ambos os inclinam a tudo que gravita, como os textos, entre a "dualidade e o ambíguo" (LINS, 1973, p. 36). Neste momento, a narrativa é abruptamente atravessada pelo enunciado, escrito em itálico, "Marechal Costa e Silva apoia o voto indireto" (LINS, 1973, p. 36). O que poderia ser uma questão arquetípica (a dualidade do eclipse) é atravessado por um dado histórico, qual seja, um dos passos do estado de exceção civil-militar brasileiro que culminaria, posteriormente, no Ato Institucional no 5, instalado no Brasil em 1968, concedendo poderes ilimitados ao presidente da República. Logo após, em momento de reflexão no cais em " $T$ " da cidade de Ubatuba, Abel especula: "o modo exasperado e ostensivo como a opressão venera a Ordem faz-me supor que disfarça uma filiação ao Caos", pois, continua o narrador, "a ordem, para o opressor, é um reflexo degenerado das leis que 
regem o Cosmos: rigidamente concebida, tende à petrificação" (LINS, 1973, p. 48). Se o Iólipo, uma estranha criatura inventada por Lins para representar o absoluto "mal", a "opressão" por excelência, e que é sempre masculina, estéril - e torna igualmente estéril o ventre que a gera - e habita a escuridão, poderia ser entendido como a pura negatividade, a exclusiva violência e destruição, aqui se revela sua ligação, justamente, com a veneração à ordem. Aliás, Olavo Hayano, o algoz de Avalovara que mata Abel e sua amada ao fim da estória - concedendo à narrativa um caráter trágico - era um Iólipo e, na condição de militar, possuía um amor ao rigor, à ordem petrificada, à hierarquia. Com isto, o trecho trabalhado aponta para duas dimensões: a primeira é histórica e diz respeito ao senso comum que circulava na época, segundo o qual o advento do golpe militar era necessário para interditar a baderna; a outra é antropológica, pois mostra como uma posição tão característica da nossa civilização, a saber, a propensão à ordem absoluta, à pura racionalidade, à positividade plena, encerra-se em uma violência sem precedentes. Isto Abel percebia muito bem ao demandar o "indizível", a negatividade, o não saber como modo de livrar seu texto da opressão.

A amada de Abel, $\odot$, encena esta lógica de forma bastante interessante: ela é uma figura primitiva que deixa o Brasil central e chega a São Paulo sem saber falar, apenas monta e desmonta palavras (LINS, 1973, p. 29), o que a leva a se comparar a um cão: seus pais, por sua vez, acreditam que $\odot$ possui o demônio no corpo (LINS, 1973, p. 113). Ela é estuprada pelo seu marido Inácio Gabriel (LINS, 1973, p. 22), encontra uma bala de revólver encravada em seu corpo (LINS, 1973, p. 51) e, no fragmento "O 4", há uma menção ao seu segundo nascimento (o eixo temático que traça sua biografia se intitula "História de $\odot$ : nascida e nascida" em alusão ao primeiro nascimento, biológico, da personagem e ao subsequente enquanto linguagem, remontando ao já citado problema blanchotiano da nomeação presente em Nove, novena):

Assim vivo, nesta comunhão que me multiplica e me atormenta, assim vivo até precipitar-me para baixo no meu velocípede, eu e o mundo, eu e as três rodas que giram em derredor de mim, e tudo escurece e nessa escuridão eu sou novamente formulada, eu, novamente sou parida, sim, nasço outra vez (LINS, 1973, p. 29). 
Todavia, se Maurice Blanchot, baseado em Hegel, dizia que nomear aniquila, mata a coisa "na existência" (BLANCHOT, 2011, p. 331), o renascimento de $\odot$ se dá a partir de sua morte, matizada pelo projétil que carrega no peito e por ter sido arremessada no vão do elevador do edifício Martinelli, onde morava com seus pais. No fragmento "O 13", $\odot$ menciona que uma adolescente teria sido encontrada "violada e morta no poço dum elevador" (LINS, 1973, p. 106) e que nem por isso ela havia sido impedida de circular pelo prédio. Daí, confessa:

ninguém sabe que sou outra desde a queda naquele mesmo poço, ou que o mundo desde então é outro para mim, ninguém, e mesmo assim, nenhuma chave é retirada das fechaduras, as telas de aço originariamente destinadas a impedir que me precipite das janelas se desfazem, não resistem sequer a um bico de pardal e eu vago sozinha, livremente, nesses corredores onde há um estuprador. Por que não continuam a proteger-me? (LINS, 1973, p. 106).

No fragmento seguinte, "O 14", $\odot$ diz: "Vou ao elevador [...] em que me precipito com o velocípede, chamo-o; não o utilizo; volto, fecho a porta e retomo meu lugar no sofá" (LINS, 1973, p. 110). Lança, então, os olhos sobre seu pai e sua mãe e se pergunta: "são meus pais? Ou são meus assassinos?" (LINS, 1973, p. 111). Posteriormente, fita sua mãe e espera que ela traga a notícia de sua morte (LINS, 1973, p. 111). Em "O 16", ao novamente olhar para sua mãe, $\odot$ diz: "ela me impede [...] de cair para que eu não morra, eu tombo no poço do elevador quebrado, e nasço", e continua, "quando, deixando as chaves na porta, invocando armadilhas para que eu me arrebente de uma vez por todas, capto essa intenção e mato-a em mim, mato em mim pai e mãe" (LINS, 1973, p. 138). Desta maneira, o texto deixa entrever que a personagem é morta pelos pais, que a empurram - ou são omissos em relação ao perigo de sua queda - no poço ou em direção à "bala de calibre 38" (LINS, 1973, p. 139) que ela aloja no peito.

Desta sorte, $\odot$ ', enferma, em recuperação pela queda no poço, pelo tiro ou pelo estupro que sofreu, presencia "a montagem da máquina" (LINS, 1973, p. 133) que, encravada em seu corpo e intelecto, transforma-a em um ser "para onde converge, com suas múltiplas faces, o que o homem conhece, o que julga conhecer, o de que suspeita, o que imagina e o que nem sequer lhe ocorre que exista" (LINS, 1973, 
p. 135). Encena-se agora, de forma explícita, o segundo nascimento da personagem, enquanto palavra, ou melhor, como linguagem, conhecimento, que é, justamente, aquilo que nos separa dos animais. $\mathrm{O}$ interessante deste processo é que, quando Abel começa a beijá-la de forma intensa, $\odot$ declara que o erotismo violento que dali decorre lhe permite assistir à "desagregação da máquina. As palavras se extraviam por suas aberturas e vãos" (LINS, 1973, p. 201). Numa cena anterior, estas lacunas oriundas da relação sexual ganham seu aspecto primitivista, uma vez que a personagem, ao encontrar Abel no tapete, cita os melanésios e afirma: "Que eu não arranque os pés a esta hora de cambiante e lúcida plumagem: nela mergulhar com toda a minha carga de animal" (LINS, 1973, p. 112). Não obstante, quando transferida pelo sexo com Abel ao tapete, no qual seu corpo se torna poroso e absorve os desenhos que ali estão (LINS, 1973, p. 45), ela testemunha um animismo disparatado com o advento de uma pletora de animais fantásticos que, inclusive, participam da relação sexual, como ocorre com um crocodilo e um coelho (LINS, 1973, p. 47). Desta forma, a negatividade da inconstante vida biológica/animal, da qual o primitivismo inscrito no êxtase do erotismo pansexual e animista de $\odot$ com Abel é um dos desdobramentos, possui a capacidade de desmontar a máquina do mundo, a máquina antropológica do conhecimento, concedendo uma forma de vida alegre a $\odot{ }_{-}$" $O$ me felicem!!" (LINS, 1973, p. 111), dizia ela ao encontrar Abel -, em meio a uma violência descomunal com que a linguagem, assim como a civilização, submete a personagem. Junto a Abel, seu corpo perfura as palavras e libera as imagens do tapete que se tornam seres reais, capazes de atuar no mundo das personagens, embora, devido aos seus aspectos, pareçam ser oriundos do Livro dos seres imaginários, de Borges. Enfim, dá-se uma multiplicidade (de formas de vida, da imaginação etc.), em oposição à ideia de unidade que subjaz à noção de conhecimento tal como engendrada pela tradição ocidental.

Abel, por sua vez, como escritor que parece dar forma e fundo ao romance que estamos lendo, começa a escrevê-lo a partir de um manuscrito que lhe é entregue por engano numa biblioteca de Veneza. Nele consta um poema apócrifo e incompleto - o que é bastante borgeano -, do qual o brasileiro retira uma sentença que guiará sua obra. Tal expressão teve sua origem há 200 a.C., quando Publius Ubônius promete libertar seu escravo Loreius - que não seria crucificado se tentasse fugir (LINS, 1973, p. 31) - caso decifrasse um enigma, qual seja, encontrar uma frase que 
possa ser lida "indiferentemente da esquerda para a direita, e ao revés", assim como "de cima para baixo" (LINS, 1973, p. 95), contanto que o sentido não se alterasse. Desta maneira, a sentença simbolizaria o ímpeto místico do senhor, a saber: que "sobre um campo instável, o mundo", reine "uma vontade imutável" (LINS, 1973, p. 32). Para tanto, Loreius elege o termo tenet, que evoca a imutabilidade tanto pela sua forma anacíclica, quanto pelo seu sentido, qual seja, "ter, posse, propriedade, condução e direcionamento" (LINS, 1973, p. 31). Além disso, escreve-o em diversas direções, de modo a engendrar a letra " $T$ " em forma de cruz, que era o instrumento de tortura dos escravos, como já dito. Para dar margem à instabilidade do mundo, pois somente com a possibilidade de o mundo ser variável ele poderia se libertar um dia, Loreius nota que o crucifixo formado por tenet possui a partícula net, cujo significado, segundo o dialeto estrangeiro que falavam seus pais, significaria "não mais". Com a frase "sator arepo tenet opera rotas" montada pelo escravo, cujo significado é "o lavrador mantém cuidadosamente a charrua nos sulcos" e o "lavrador sustém cuidadosamente o mundo em sua órbita", poder-se-ia atender ao ímpeto místico do amo: o mundo mantido em órbita, o lavrador mantendo seu arado, uma vontade imutável reinando sobre uma physis mutante.

Porém, a resolução da charada implica a retirada da cruz da tortura, findando a propriedade do amo sobre o escravo, mas o enigma também é, em sua forma, a extração do "T" da palavra, de modo que se perceba, em acordo com uma língua estrangeira, que há net em tenet. Assim, com a leitura de Loreius, que está à margem da cultura dominante por ser estrangeiro e, logo, escravo, tenet é um termo paradoxal e faz a expressão significar, simultaneamente, tanto "o lavrador mantém cuidadosamente a charrua nos sulcos" ou "o lavrador sustém cuidadosamente o mundo em sua órbita", quanto "o lavrador não mais mantém cuidadosamente a charrua nos sulcos" e "o lavrador não mais sustém cuidadosamente o mundo em sua órbita". Assim, "sobre um campo instável, o mundo" não mais reina "uma vontade imutável", isto é, a vontade de Ubônius não mais conduz Loreius. A máquina agrícola que mantém o arado, o mundo em órbita - assim como guiaria o livro de Abel - e Loreius enquanto escravo, por uma falha epistemológica, um paradoxo, abre-se ao acaso (a possibilidade do fim da relação amo/escravo) e à imprevisibilidade da physis, pois, como mesmo diz Avalovara, com esta fresta temos o advento das "patas sanguíneas de um cavalo" que ceifariam, esmagariam 
e incendiariam as lavouras rigorosamente ordenadas pelas charruas além de um anímico "abismo aquático, infestado de sereias, de peixes cantores, grandes hipocampos alados e aves que não pousam" (LINS, 1973, p. 72). Não é fortuitamente que Janos simboliza o livro de Abel, aquele deus paradoxal e reversível que olha para frente e para trás e que, tendo como insígnia a chave e a vara, convida e expulsa ao mesmo tempo. Por isso, ele poderia responder à pergunta de Abel quando este indaga: "como, então, fazer repousar a arquitetura de uma narrativa, objeto propenso ao concreto, sobre uma entidade ilimitada e que os nossos sentidos, hostis ao abstrato, repudiam?" (LINS, 1973, p. 17), pergunta, aliás, muito próxima daquela que a narrativa se põe quando a personagem Julius Heckethorn constrói seu relógio: "sabemos [...] que o relógio de Julius Heckethorn [...], ou melhor, seus aprestos de som, obedecem a um esquema rigoroso. Sobre este rigor assenta a ideia de uma ordem no mundo. Como introduzir, então, na obra", finaliza o narrador, "o princípio de imprevisto e de aleatório, inerente à vida?" (LINS, 1973, p. 347).

A opressão, então, configura-se como ordem imutável, petrificada, como uma máquina do mundo e seu conhecimento absoluto, que não pode ser tocado ou transformado e que, em seu ímpeto de absoluta positividade, acaba por encerrar uma violência, uma negatividade sem precedentes, assim como a servidão sem fim a que impele, finalmente, o próprio mundo, o ambiente circundante. Em Nove, novena a ideia da imutabilidade ganha representação, também, com a figura do burocrata. O assassino de "Conto barroco" declarava que deveria aniquilar suas vítimas como quem aplica "um carimbo sob um texto para assinatura" (LINS, 2004, p. 134). Porém, se como epígrafe desta obra Lins usou a imagem de um edifício surgindo de suas forças simples, como consta no poema cabralino "O engenheiro", no conto "Noivado", no qual são narradas as vicissitudes do burocrata Mendonça, a imagem inicial é a de uma repartição pública sendo corroída, colocada abaixo pelos insetos. Os animais que, como diz o conto perto do seu encerramento, "sondam as possibilidades do mundo" (LINS, 2004, p. 168), são capazes de colocar no tempo as vontades imutáveis dos homens - o que serve de ensejo para encerrar um kafkiano, opressor e violento noivado, que nunca se transforma em casamento, refuncionalizando as vidas das personagens. O engenheiro se torna bricoleur.

Neste sentido, o olhar de Machado sobre Lins nos parece interessante: ao passo que assinala no escritor um ímpeto de transferir 
aos animais o conhecimento, o imutável transcendental, que seria a especificidade dos homens, ele, por outro lado, coloca no espaço-tempo todo o ímpeto de imutabilidade e invariabilidade, abrindo a jaula na qual se movem os animais selvagens, as formas de vida múltiplas e indomesticáveis, que também podem residir no interior do próprio homem. Aliás, é precisamente com o encerramento do domínio humano sobre o ambiente - domínio este que parece gerar apenas o tédio da burocracia, a reificação das vidas e a violência brutal das relações petrificadas e perenemente hierarquizadas -, que em muitos momentos tem como base a epistemologia, o conhecimento, que se dá lugar ao advento do animismo nos citados textos osmanianos. Se o saber eterno e imutável - como aquele que pretende o olho de vidro, a escrita e a alquimia - não está conosco, vide a violência que produzimos, ele pode estar em outro lugar, como nos seres não humanos. Todavia, o animismo de Lins geralmente traz seres fantásticos - que estão lá, olhando-nos - e uma espécie de ecologia disparatada, o que parece acontecer por um motivo específico: um antropomorfismo completo e verossímil reduziria os seres não humanos ao conhecimento que fazemos deles, e o problema aqui passa, sobretudo, por uma crítica ao saber, que se encontra desarticulado pelo advento do paradoxo, da sombra, do incompreensível, da evocação mágica citada pelo autor. Esta evocação, por sua vez, parece ser tirada de alguns mitos dos povos tradicionais que Lins afirmava ser parte constituinte da literatura latino-americana de maneira geral. Assim como a destruição do prédio no conto "Noivado", a partícula net na frase construída por Loreius, a desarticulação das palavras e o advento dos animais no erotismo de $\odot$ com Abel, a entrada de Hahn na pequena cidade pernambucana e a sua suposta assinatura da carta, parecem seguir o exemplo dado por Eliade acerca da reatualização do mito no ritual selvagem. Pois é a partir da quebra em uma norma estabelecida, acabando com a distinção entre nómos e physis e levando ao fim um modo petrificado de se relacionar com o ambiente circundante, que se pode dar lugar à criação, à renovação, à reinvenção e à libertação, ou seja, a novas formas de vida, de habitar o mundo, como acontece com as personagens osmanianas: Giselda se liberta do noivado opressor, a menina encontra uma luz em sua vida apagada ao conhecer Hahn etc. Enfim, a cultura sem a natureza (o olho de vidro que não precisa do órgão sensível, as ordens e hierarquias petrificadas do militar Hayano) se mostra, em Osman Lins, como ordem violenta e bárbara, e a natureza, 
neste sentido, é capaz de se mostrar como cultura, ou seja, uma forma de vida, um hábito libertador, como o é o erotismo de Abel com $\odot$, no qual uma natureza disparatada se revela.

Por outro lado, Lins parece se colocar muito longe da ideia de arquétipo, sobretudo ao fazer questão de citar diversos dados históricos, o que seria contrário à natureza a-histórica dos dispositivos arquetípicos. Tal procedimento, aliás, possui uma grande importância em seus escritos e parece ter a função de retirar o dado histórico de um lugar estanque no passado para colocá-lo na ordem do dia, com sua possibilidade de vir a ser novamente para que nós, inclusive, possamos impedir que ele se repita num disfarce de diferença, ou seja: o fato de Osman Lins fazer referência direta à ditadura, por exemplo, permitir-nos-ia especular de que maneira estaríamos ou não distantes deste violento regime político pelas práticas que ainda possuímos no presente, mesmo que no interior de um suposto regime democrático. Assim, a literatura de Osman Lins angaria uma tarefa singular: ao passo que formula uma crítica tanto histórica quanto antropológica das consequências de a civilização julgar ter um conhecimento que se quer absoluto, de verdades invariáveis e petrificadas que, no entanto, apenas controlam e subjugam o mundo e os próprios homens, o autor transporta-nos, por outro lado, a um entre-lugar muito especial, no qual as palavras voam e os bichos escrevem.

\section{Referências}

BLANCHOT, M. A parte do fogo. Tradução de Ana Maria Scherer. Rio de Janeiro: Rocco, 2011.

ELIADE, M. O sagrado e o profano. A essência das religiões. Tradução de Rogério Fernandes. São Paulo: Martins Fontes, 2011.

GHYKA, M. C. Estética de las proporciones em la natureza y em las artes. Tradução de J. Bosch Bousquet. Buenos Aires: Editorial Poseidon, 1953.

GHYKA, M. C. Philosophie et mystique du nombre. Paris: Payot, 1952. JUNG, C. G. Os arquétipos e o inconsciente coletivo. Tradução de Maria Luiza Appy e Dora Mariana R. Ferreira da Silva. Petrópolis: Vozes, 2006.

KIRSCH, G. F. Poética da tradução e recepção estética. Nove, novena na França e na Alemanha. 1998. Tese (Doutorado em Teoria Literária 
e Literatura Comparada) -Faculdade de Filosofia, Letras e Ciências Humanas, Universidade de São Paulo, São Paulo, 1998.

LÉVI-STRAUSS, C. O pensamento selvagem. Tradução de Tânia Pellegrini. Campinas: Papirus, 1989.

LINS, O. A rainha dos cárceres da Grécia. São Paulo: Melhoramentos, 1976.

LINS, O. Avalovara. São Paulo: Melhoramentos, 1973.

LINS, O. [Entrevista de Osman Lins concedida a Edla van Steen]. Viver e Escrever, Porto Alegre, Editora L\&PM, v. 1, c1981. Disponível em: $<\mathrm{http}$ ://www.osman.lins.nom.br/entrevista.asp? $\mathrm{id}=5>$. Acesso em: 29 out. 2016.

LINS, O. Evangelho na taba. Outros problemas inculturais brasileiros. São Paulo: Summus, 1979.

LINS, O. Nove, novena. Narrativas. 4. ed. São Paulo: Companhia das Letras, 2004.

LINS, O. Retable de Sainte Joana Carolina. Tradução de Maryvonne Lapouge. Paris: Les Lettres Nouvelles, 1971.

MACHADO, A. M. Osman Lins, artisan et alchimiste. Magazine littéraire., Paris, n. 59, p. 29-30, déc. 1971.

NETO, J. C. de M. O engenheiro. In: Rio de Janeiro: Nova Aguilar, 2008. p. 45-46. . Poesia e prosa completa.

NIETZSCHE, Friedrich. A origem da tragédia. Tradução de Joaquim José de Faria. 13. ed. São Paulo: Centauro, 2004.

PAES, J. P. A palavra feita vida. In: LINS, O. Nove, novena. Narrativas. São Paulo: Companhia das Letras, 2004.

PEREIRA, E. R. Na biblioteca de Osman Lins: marginália, intertextualidade e criação. In: ENCONTRO DA ABRALIC. INTERNACIONALIZAÇÃO DO REGIONAL, 13., 2012, Campina Grande. Anais... Campina Grande: UEPB/UFCG, 2012. p. 1-8.

PERRONE-MOISÉS, L. Prefácio. Tradução de Leyla Perrone-Moisés. Osmar Lins, [s.d.]. Repercussão. Disponível em: $<$ http://www.osman. lins.nom.br/repercursao.asp?id=p4>. Acesso em: out. 2015. 
PLATÃO. O banquete. Tradução de Donaldo Schüler. Porto Alegre: L\&PM, 2012.

ROBBE-GRILLET, A. Le voyeur. Paris: Les Éditions de Minuit, 1955.

SARRAUTE, N. Portrait d'un inconnu. Paris: Gallimard, 1956.

SIMON, C. Le vent. Tentative de restitution d'un retable baroque. Paris: Les Éditions de Minuit, 1957.

VAN LENNEP, J. Art \& alchimie. Étude de l'iconographie et de ses influences. Bruxelles: Meddens, 1966.

VERTOV, D. Resolução do conselho dos três em 10-4-1923. In: XAVIER, Ismail. (Org.). A experiência do cinema. Antologia. Rio de Janeiro: Graal, Embrafilmes, 1983. 